\title{
Mycobacterium komossense sp. nov.
}

\author{
J. KAZDA' ${ }^{1}$ AND K. MÜLLER ${ }^{2}$
}

Department of Microbial Ecology, Research Institute Borstel, Institute for Experimental Biology and Medicine, 2061 Borstel, ${ }^{1}$ and Department of Botany, Christian-Albrecht University of Kiel, Kiel, ${ }^{2}$ Germany

\begin{abstract}
Strains of a new type of rapidly growing, scotochromogenic mycobacterium have been isolated repeatedly from sphagnum vegetation of moors in south Sweden and the Atlantic coastal area of Norway. These strains split urea and succinamide, hydrolyze Tween 80 , produce acid from glucose, fructose, mannitol, rhamnose, sorbitol, and trehalose, and grow on a medium with fumarate, succinate, citrate, malonate, oxalate, propanol, or hippurate as the single carbon source. Furthermore, they possess acid phosphatase and putrescine oxidase activities, degrade salicylate, and metabolize iron. Additional properties of these strains are presented. The internal similarity of the strains, as determined by numerical taxonomy methods, as $94.97 \pm 3.42 \%$. A comparison with 21 species (clusters) of rapidly growing mycobacteria is also presented. The production of mycolic acid by these strains and their micromorphology confirm that they belong to the genus Mycobacterium. The strains have unique lipid and immunodiffusion patterns and form special sensitins. These strains are considered as belonging to a new species of nonpathogenic, rapidly growing mycobacteria for which we propose the name Mycobacterium komossense. Strain Ko 2 is the type strain of M. komossense; a culture of this strain has been deposited in the American Type Culture Collection under the number 33013.
\end{abstract}

During 1976 and 1977, 18 strains of Mycobacterium with similar properties were isolated from sphagnum vegetation of intact sphagnum bogs in south Sweden and the Atlantic coastal area of Norway. These strains were found only in intact sphagnum vegetation and not in partially cultivated moors. The properties of these strains indicate that they belong to a new species. This paper reports the results of a taxonomic study of these unusual strains.

\section{MATERIALS AND METHODS}

Bacterial strains. The designations and the sources of the 18 heretofore-undescribed strains of mycobacteria (referred to herein as the Ko strains) are recorded in Table 1.

Methods. The colonial morphology and the ability to grow at various temperatures $\left(22,31\right.$, and $\left.37^{\circ} \mathrm{C}\right)$ were determined after 1 week of incubation on Löwenstein-Jensen and 7H10 Middlebrook agar inoculated with $10^{-2} \mathrm{mg}$ of cells per plate. Pigment production in the dark and photoactivity after 1 week of incubation were determined as previously described $(4,22)$. The following tests were also performed as described previously: growth on MacConkey agar (15); resistance to $250 \mu \mathrm{g}$ of hydroxylamine $(20), 0.2 \% p$ aminosalicylic acid (22), $20 \mu \mathrm{g}$ of sodium azide per ml $1 \%$ sodium deoxycholate, $3 \%$ sodium chloride, and $0.1 \%$ sodium nitrite $(16,22,24)$; iron uptake $(19)$; nitrate reduction (2); arylsulfatase activity in 3 days (10); acid phosphatase production in $4 \mathrm{~h}$ at $31^{\circ} \mathrm{C}(6)$; and production of acetamidase, benzamidase, urease, isonicotinamidase, nicotinamidase, pyrazinamidase, salicylamidase, allantoinase, succinamidase, and malonam- idase (1) and of putrescine oxidase (3). The production of acid from glucose, rhamnose, xylose, arabinose, mannose, galactose, mannitol, sorbitol, inositol, dulcitol, trehalose, and fructose was tested in an agar medium during 3 weeks of incubation (5). The utilization of fumarate, succinate, citrate, malonate, oxalate, benzoate, hippurate, and propanol as sole carbon sources and of acetamide, benzamide, and trimethylenediamine as sole carbon and nitrogen sources was determined by the method of Tsukamura (23). The degradation of salicylate was also determined by a previously described method (21).

Cells suspended in distilled water were placed on specimen grids (3 mm, Cu, type 300 ) for electron microscopy, washed with distilled water, and air dried. The cells were then shadowed (electron beam evaporation) at an angle of $35^{\circ}$ with platinum-carbon. The electron microscope used was a Philips EM $300(80$ $\mathrm{kV}$ ) with Kodak planfilm no. 4489 . The production of mycolic acid by six of the Ko strains and by Mycobacterium smegmatis SN 2, a freshly isolated strain of Mycobacterium chelonei, and Nocardia opaca SN 5900 was determined chromatographically (13). The Jones-Mote reaction was determined as previously described (7). For the pathogenicity test, a 4-day-old culture of strain Ko 11 was used. Five rabbits were infected intravenously with $10 \mathrm{mg}$ of bacterial mass (semi-wet weight), five mice were infected intravenously with $1 \mathrm{mg}$, and five guinea pigs were infected subcutaneously with $10 \mathrm{mg}$. After 8 weeks, the animals were sacrificed and examined (12).

Lipid production by five strains (Ko 1, 4, 5, 6, and 7) was determined by P. A. Jenkins (Cardiff, England) (11), and the immunodiffusion test was performed on these strains by J. L. Stanford (London, England) (18). 
A comparison of the properties of three strains (Ko 2, 9 , and 11) with those of the known mycobacterial species was performed by M. Tsukamura (Obu, Japan).

Numerical analysis. Based on the comparison of 52 properties, the internal similarity $(S)$ of the $18 \mathrm{Ko}$ strains was determined (17). The properties of 16 species of rapidly growing mycobacteria as reported by Saito et al. (16) and the properties of Mycobacterium aichiense ATCC 27280 and 27281 and Tsukamura 49002, Mycobacterium chubuense ATCC 27278 and 27279 and Tsukamura 48014, Mycobacterium obuense ATCC 27023, Mycobacterium duvalii NCTC
358, and Mycobacterium gilvum NCTC 10742 were determined and compared with those of Ko 2. All data obtained were converted to the simple binary form (i.e., 1 or 0 ) for analysis $(16,17)$. A total of 46 properties were compared; in Mycobacterium phlei, Mycobacterium fortuitum, Mycobacterium thamnopheos, Mycobacterium abscessus, and Mycobacterium chelonei, only 45 properties could be compared.

\section{RESULTS}

The cells of the 18 strains grown on Löwenstein-Jensen medium and on Middlebrook 7H10

TABLE 1. Strains used in this study

\begin{tabular}{lll}
\hline Strain & \multicolumn{1}{c}{ Source } & \multicolumn{1}{c}{ Locality } \\
\hline Ko 1 & $\begin{array}{l}\text { Sphagnum compactum and Sphagnum } \\
\text { molle } \\
\text { Sphagnum compactum and Sphagnum } \\
\text { molle } \\
\text { Ko } 2\end{array}$ & Komosse moor, south Sweden \\
Ko 3 & $\begin{array}{l}\text { molle } \\
\text { Sphagnum cuspidatum }\end{array}$ & Komosse moor, south Sweden \\
Ko 4 & Sphagnum tenellum & Komosse moor, south Sweden \\
Ko 5 & Sphagnum tenellum & Komosse moor, south Sweden \\
Ko 6 & Sphagnum balticum & Komosse moor, south Sweden \\
Ko 7 & Sphagnum balticum & Komosse moor, south Sweden \\
Ko 8 & Sphagnum recurvum & Komosse moor, south Sweden \\
Ko 9 & Sphagnum recurvum & Komosse moor, south Sweden \\
Ko 10 & Aulacomnium palustre & Komosse moor, south Sweden \\
Ko 11 & Aulacomnium palustre & Komosse moor, south Sweden \\
Ko 12 & Aulacomnium palustre & Komosse moor, south Sweden \\
Ko 13 & Sphagnum papillosum & Komosse moor, south Sweden \\
Ko 14 & Sphagnum rubellum & Komosse moor, south Sweden \\
Ko 15 & Sphagnum imbricatum & Norway coast, island of Sotra \\
Ko 16 & Sphagnum rubellum & Norway coast, Stonefjord region \\
Ko 17 & Sphagnum fallax & Norway coast, island of Hitra \\
Ko 18 & Norway coast, island of Hitra \\
\hline
\end{tabular}

a Strains Ko 1 through 17 were isolated in 1976 , and Ko 18 was isolated in 1977.

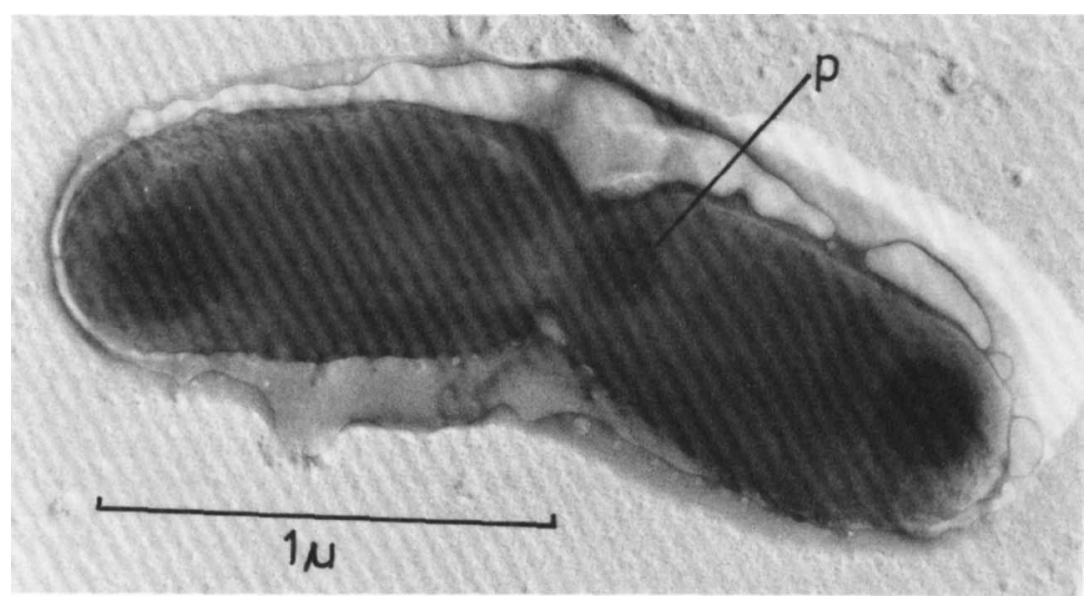
(p).

FIG. 1. Cells of M. komossense strain Ko 11 showing a slime layer and reserve particles of polyphosphate 
TABLE 2. Characters of 18 Ko strains

\begin{tabular}{|c|c|}
\hline Character & $\begin{array}{l}\% \text { of strains } \\
\text { giving positive } \\
\text { reaction }\end{array}$ \\
\hline Pigment production in the dark $\ldots .$. & 100 \\
\hline Photoactivity after $1 \mathrm{wk}$ & 0 \\
\hline Growth at $22^{\circ} \mathrm{C}$ in 7 days & 100 \\
\hline Growth at $31^{\circ} \mathrm{C}$ in 4 days & 100 \\
\hline Growth at $37^{\circ} \mathrm{C}$ in 7 days $\ldots$ & 100 \\
\hline 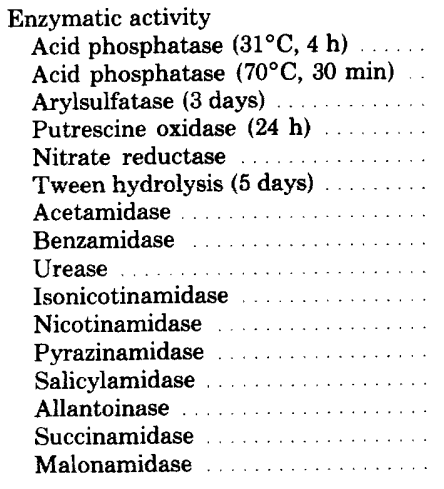 & $\begin{array}{r}100 \\
100 \\
0 \\
100 \\
0 \\
94^{a} \\
6^{b} \\
6^{c} \\
100 \\
0 \\
11^{d} \\
17^{e} \\
0 \\
0 \\
100 \\
39^{f}\end{array}$ \\
\hline 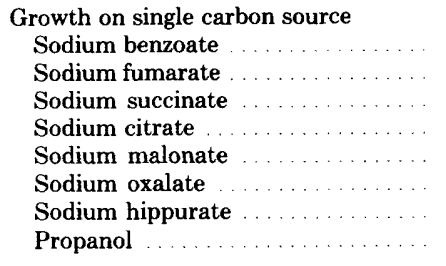 & $\begin{array}{r}0 \\
100 \\
100 \\
100 \\
100 \\
100 \\
100 \\
100\end{array}$ \\
\hline $\begin{array}{l}\text { Growth on single nitrogen/carbon } \\
\text { source } \\
\text { Acetamide } \ldots \ldots \ldots \ldots \ldots \ldots \ldots \ldots \\
\text { Benzamide } \ldots \ldots \ldots \ldots \ldots \ldots \\
\text { Trimethylendiamine } \ldots \ldots \ldots \ldots \ldots\end{array}$ & $\begin{array}{r}100 \\
0 \\
100\end{array}$ \\
\hline $\begin{array}{l}\text { Growth in presence of: } \\
\text { Hydroxylamine }(250 \boldsymbol{\mu g}) \ldots \ldots \ldots \\
\text { Azide }(20 \boldsymbol{\mu g}) \ldots \ldots \ldots \\
\text { Deoxycholate }(1 \%) \ldots \ldots \ldots \ldots \\
\begin{array}{l}\mathrm{NaCl}(3 \%) \\
\mathrm{NaNO}_{2}(0.1 \%)\end{array} \ldots \ldots \ldots \ldots \ldots \ldots \ldots \ldots\end{array}$ & $\begin{array}{r}0 \\
100 \\
0 \\
6^{k} \\
100\end{array}$ \\
\hline Growth on MacConkey agar & 0 \\
\hline Degradation of salicylate $\ldots \ldots \ldots \ldots$ & 100 \\
\hline Iron uptake $\ldots \ldots \ldots \ldots \ldots \ldots$ & 100 \\
\hline 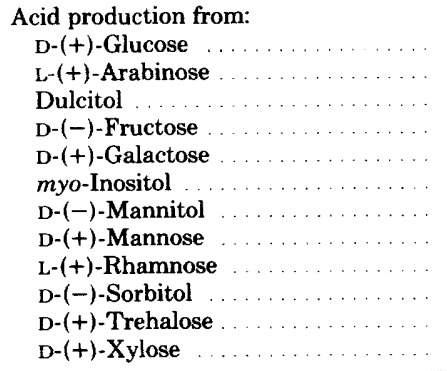 & $\begin{array}{r}100 \\
0 \\
0 \\
100 \\
0 \\
39^{h} \\
100 \\
67^{i} \\
100 \\
100 \\
94^{j} \\
0\end{array}$ \\
\hline
\end{tabular}

${ }^{a}$ Strain Ko 13 was negative.

${ }^{b}$ Strain Ko 5 was positive.

'Strain Ko 5 was positive.
${ }^{d}$ Strains Ko 5 and Ko 15 were positive.

e Strains Ko 5, Ko 15, and Ko 16 were positive.

' Strains Ko 5, Ko 6, Ko 10, Ko 12, Ko 15, Ko 16, and Ko 18 were positive.

${ }^{z}$ Strain Ko 16 was positive.

${ }^{h}$ Strains Ko 1, Ko 4, Ko 5, Ko 7, Ko 11, Ko 17, and Ko 18 were positive.

i Strains Ko 6, Ko 8, Ko 13, Ko 14, Ko 16, and Ko 18 were negative.

${ }^{j}$ Strain Ko 8 was negative.

agar were short to moderately long, gram-positive, acid-alcohol-fast rods which often formed clumps, but not cords or crossbands (Fig. 1). Spores, capsules, true branching, and aerial hyphae were not observed.

On Löwenstein-Jensen medium, all of the strains produced eugonic, smooth, glistening, yellow-beige-pigmented colonies when incubated between 22 and $37^{\circ} \mathrm{C}$. At $31^{\circ} \mathrm{C}$, growth was observed after 3 days; at 22 and $37^{\circ} \mathrm{C}$, it was observed after 7 days. Dilute inocula on Middlebrook agar yielded smooth, compact, glistening, yellow-beige colonies 0.5 to $2 \mathrm{~mm}$ in diameter and with entire margins.

The results of the tests on 52 properties of the 18 Ko strains are recorded in Table 2. These strains constitute a homogeneous group with an internal similarity of $94.97 \pm 3.42 \%$ (Table 3 ). A comparison of the properties of the Ko 2 strain with those of 21 species (clusters) of rapidly growing mycobacteria shows that they differ from hitherto-described species (Table 4).

On the basis of their mycolic acid production, the six Ko strains showed a close relationship to the genus Mycobacterium but a distinct difference from Nocardia. The Jones-Mote reaction in the Ko 2 strain was positive with the homologous sensitin but negative with the sensitins prepared from Mycobacterium avium, Mycobacterium borstelense, Mycobacterium bovis, Mycobacterium chelonei, Mycobacterium flavescens, Mycobacterium fortuitum, Mycobacterium gastri, Mycobacterium gordonae, Mycobacterum intracellulare, Mycobacterium kansasii, Mycobacterium marinum, Mycobacterium nonchromogenicum, Mycobacterium phlei, Mycobacterium scrofulaceum, Mycobacterium smegmatis, Mycobacterium terrae, My. cobacterium triviale, and Mycobacterium xenopi. When testing for pathogenicity, we found that strain Ko 11 produced neither organic nor local lesions in infected rabbits, guinea pigs, or mice. With respect to their lipid patterns (investigated by P. A. Jenkins), the Ko strains were homogeneous but were different from all other known rapidly growing mycobacterial species. The immunodiffusion tests (performed by J. L. Stanford) also showed no relationship of the Ko 
TABLE 3. Similarity matrix of the Ko strains (S:100)

\begin{tabular}{|c|c|c|c|c|c|c|c|c|c|c|c|c|c|c|c|c|c|c|}
\hline$:$ & 1 & 2 & 3 & 4 & 5 & 6 & 7 & 8 & 9 & 10 & 11 & 12 & 13 & 14 & 15 & 16 & 17 & 18 \\
\hline $1:$ & 1.00 & 0.98 & 0.98 & 1.00 & 0.90 & 0.94 & 1.00 & 0.94 & 0.98 & 0.96 & 1.00 & 0.98 & 0.94 & 0.96 & 0.92 & 0.90 & 1.00 & 0.94 \\
\hline $2:$ & & 1.00 & 1.00 & 0.98 & 0.88 & 0.96 & 0.98 & 0.96 & 1.00 & 0.98 & 0.98 & 1.00 & 0.96 & 0.98 & 0.94 & 0.92 & 0.98 & $\overline{0.92}$ \\
\hline $3:$ & & & 1.00 & 0.98 & 0.88 & 0.96 & 0.98 & 0.96 & 1.00 & 0.98 & 0.98 & 1.00 & 0.96 & 0.98 & 0.94 & 0.92 & 0.98 & 0.92 \\
\hline 4: & & & & 1.00 & 0.90 & 0.94 & 1.00 & 0.94 & 0.98 & 0.96 & 1.00 & 0.98 & 0.94 & 0.96 & 0.92 & 0.90 & 1.00 & 0.94 \\
\hline $5:$ & & & & & 1.00 & 0.88 & 0.90 & 0.84 & 0.88 & 0.90 & 0.90 & 0.88 & 0.84 & 0.86 & 0.94 & 0.88 & 0.90 & 0.88 \\
\hline $6:$ & & & & & & 1.00 & 0.94 & 0.96 & 0.96 & 0.98 & 0.94 & 0.96 & 0.96 & 0.98 & 0.94 & 0.96 & 0.94 & 0.96 \\
\hline $7:$ & & & & & & & 1.00 & 0.94 & 0.98 & 0.96 & 1.00 & 0.98 & 0.94 & 0.96 & 0.92 & 0.90 & 1.00 & 0.94 \\
\hline 8: & & & & & & & & 1.00 & 0.96 & 0.94 & 0.94 & 0.96 & 0.96 & 0.98 & 0.90 & 0.92 & 0.94 & 0.92 \\
\hline 9: & & & & & & & & & 1.00 & 0.98 & 0.98 & 1.00 & 0.96 & 0.98 & 0.94 & 0.92 & 0.98 & 0.92 \\
\hline 10: & & & & & & & & & & 1.00 & 0.96 & 0.98 & 0.94 & 0.96 & 0.96 & 0.94 & 0.96 & 0.94 \\
\hline 11: & & & & & & & & & & & 1.00 & 0.98 & 0.94 & 0.96 & 0.92 & 0.90 & 1.00 & $\overline{0.94}$ \\
\hline 12: & & & & & & & & & & & & 1.00 & 0.96 & 0.98 & 0.94 & 0.92 & 0.98 & 0.92 \\
\hline 13: & & & & & & & & & & & & & 1.00 & 0.98 & 0.90 & 0.92 & 0.94 & 0.92 \\
\hline 14: & & & & & & & & & & & & & & 1.00 & 0.92 & 0.94 & 0.96 & 0.94 \\
\hline 15: & & & & & & & & & & & & & & & 1.00 & 0.94 & 0.92 & 0.90 \\
\hline 16: & & & & & & & & & & & & & & & & 1.00 & 0.90 & 0.92 \\
\hline 17: & & & & & & & & & & & & & & & & & 1.00 & 0.94 \\
\hline 18: & & & & & & & & & & & & & & & & & & 1.00 \\
\hline
\end{tabular}

TABLE 4. Similarity values between strain Ko 2 and strains of 21 species of rapidly growing mycobacteria

\begin{tabular}{|c|c|}
\hline Mycobacterium species & $\%$ Similarity \\
\hline M. aichiense & 69.6 \\
\hline$\ldots \ldots \ldots \ldots$ & 67.4 \\
\hline M. phlei & 66.7 \\
\hline M. duvalii & 63.0 \\
\hline M. gilvum & 63.0 \\
\hline M. parafortuitum & 60.9 \\
\hline M. obuense ..... & 60.9 \\
\hline M. fortuitum & 60.0 \\
\hline M. vaccae & 58.7 \\
\hline M. kanazawai . . . . . . . & 58.7 \\
\hline$M$. thamnopheos . . . . . . . & 57.8 \\
\hline$M$. diernhoferi $\ldots \ldots \ldots \ldots$ & 56.5 \\
\hline M. flavescens . . . . . . . . & 56.5 \\
\hline$M$. neoaurum . . . . . . . . & 56.5 \\
\hline M. smegmatis . . & 54.3 \\
\hline M. chitae $\ldots \ldots \ldots \ldots$ & 54.3 \\
\hline M. chubuense & 50.0 \\
\hline M. abscessus & 48.9 \\
\hline M. chelonei & 48.9 \\
\hline M. thermoresistible & 47.8 \\
\hline M. lactae $\ldots \ldots \ldots \ldots \ldots$ & 41.3 \\
\hline
\end{tabular}

strains to the rapidly growing mycobacteria that were compared. When testing 118 properties of the three Ko strains, $M$. Tsukamura noted also a distinct difference from all hitherto-known mycobacterial species.

\section{DISCUSSION}

All of the Ko strains produced urease and succinamidase, an unusual amidase pattern in mycobacteria. A numerical taxonomy comparison of the properties of 21 species (clusters) of rapidly growing mycobacteria with the same properties of 18 Ko strains has shown a low similarity of the latter to any known mycobacterial species. Only with $M$. aichiense was a similarity as high as $69.6 \%$ reached, but there is a marked difference between the Ko strains and $M$. aichiense with respect to arylsulfatase and succinamidase activities, the utilization of compounds as sole carbon sources, susceptibility to hydroxylamine, and acid production from rhamnose and sorbitol.

In addition, the Ko strains are unique with respect to their lipid pattern, their immunodiffusion character, and their inability to react with the sensitins of known mycobacterial species in the Jones-Mote reaction (7). For these reasons, we regard the Ko strains as belonging to a new species, for which we propose the name Mycobacterium komossense (M.L. adj. komossensis, belonging to the Komosse sphagnum bog, one of the largest moors in south Sweden [14], the source of the first 13 Ko strains isolated). The type strain of $M$. komossense is Ko 2. A culture of this strain has been deposited in the American Type Culture Collection under the number 33013. 
Up to the present, strains of $M$. komossense have been isolated only from intact sphagnum bogs in Scandinavia; attempts to isolate them from partially cultivated moors in northwest Germany have been unsuccessful $(8,9)$.

\section{ACKNOWLEDGMENTS}

We thank P. A. Jenkins (Public Health Laboratory, Cardiff, England), who determined the lipid pattern; K.-J. Schaper (Research Institute, Borstel, Germany), who made the computer analysis; J. L. Stanford (Middlesex Hospital, London), who performed the immunodiffusion tests; $M$. Tsukamura (National Sanatorium, Obu, Japan), who investigated 118 properties of three Ko strains; and H. Völker (Institute for Microbiology, University of Kiel, Kiel, Germany), who helped produce the electron micrographs. We also express our gratitude to L. M. Irgens (Institute for Hygiene and Social Medicine, University of Bergen, Bergen, Norway) for his kind cooperation in the field investigation of sphagnum vegetation and Hilde Hahn, Werner Mohr, and Silke Begemann (Research Institute, Borstel, Germany) for their skillful technical assistance.

This work was supported by the Deutsche Forschungsgemeinschaft (grant $\mathrm{Ka} 452 / 1-2$ and Mu 500/1), by the Ministry of Youth, Family, and Health, and by the German Leprosy Relief Association.

\section{REPRINT REQUESTS}

Address reprint requests to: Dr. J. Kazda, Department of Microbial Ecology, Research Institute Borstel, Institute for Experimental Biology and Medicine, 2061 Borstel, Germany.

\section{LITERATURE CITED}

1. Bönicke, R. 1961. Die Bedeutung der Acylamidasen für die Identifizierung und Differenzierung der verschiedenen Arten der Gattung Mycobacterium. Jahresber. Borstel 5:7-87.

2. Bönicke, R. 1962. Identification of mycobacteria by biochemical methods. Bull. Int. Union Tuberc. 32:13-86.

3. Bönicke, R., and H. Nolte. 1967. Diamin-oxydasen in Mycobacterien. Zentralbl. Bakteriol. Parasitenkd. Infektionskr. Hyg. Abt. 1 Orig. 202:479-487.

4. Gordon, R. E., D. A. Barnett, J. E. Handerhan, and C. H.-N. Pang. 1974. Nocardia coeliaca, Nocardia autotrophica, and the nocardin strain. Int. J. Syst. Bacteriol. 24:54-63.

5. Gordon, R. E., and M. M. Smith. 1953. Rapidly growing, acid-fast bacteria. I. Species' descriptions of Mycobacterium phlei Lehmann and Neumann and Mycobacterium smegmatis (Trevisan) Lehmann and Neumann. J. Bacteriol. 66:41-48.

6. Käppler, W. 1965. Zur Differenzierung von Mykobakterien mit dem Phosphatase-Test. Beitr. Klin. Tuberk. 130:223-226

7. Kazda, J. 1977. Differenzierung von Mykobakterien mit der Jones-Mote-Raktion. Zentralbl. Bakteriol. Parasitenkd. Infektionskr. Hyg. Abt. 1 Orig. Reihe A 237:9095.
8. Kazda, J. 1977. Die Bedeutung der Moorbiotope für die Ökologie von Mykobakterien. Zentralbl. Bakteriol. Parasitenkd. Infektionskr. Hyg. Abt. 1 Orig. Reihe B. 165: 323-334.

9. Kazda, J., K. Müller, and L. M. Irgens. 1979. Cultivable mycobacteria in sphagnum vegetation of moors in South Sweden and coastal Norway. Acta Pathol. Microbiol. Scand. Sect. B 87:97-101.

10. Kubica, G. P., and A. L. Ridgon. 1961. The arylsulfatase activity of acid-fast bacilli. III. Preliminary investigation of rapidly growing acid-fast bacilli. Am. Rev. Respir. Dis. 83:737-740

11. Marks, J., P. A. Jenkins, and W. B. Schaefer. 1971. Thin-layer chromatography of mycobacterial lipids as an aid to classification: technical improvements: $M y c o$ bacterium avium, $M$. intracellulare. Tubercle 52:219225.

12. Meissner, G. 1959. Untersuchungen an atypischen My kobakterien. II. Vergleichende tierexperimentelle Untersuchungen zur Frage ihrer Pathogenität und Virulenz. Beitr. Klin. Tuberk. Spezifischen Tuberk. Forsch 121:365-380.

13. Minninkin, D. E., L. Alshamaony, and M. Goodfellow. 1975. Differentiation of Mycobacterium, Nocardia and related taxa by thin-layer chromatographic analysis of whole-cell methanolysates. J. Gen. Microbiol. 88:200.

14. Oswald, H. 1923. Die Vegetation des Hochmoores Komosse. Handbook of the Sven. Växtsoc., Sällsk, Uppsala.

15. Pattyn, S. R., and F. Portaels. 1972. Identification and clinical significance of mycobacteria. Zentralbl. Bakteriol. Parasitenkd. Infektionskr. Hyg. Abt. 1 Orig. Reihe A 219:114-140.

16. Saito, H., R. E. Gordon, I. Juhlin, W. Käppler, J. B. G. Kwapinski, C. McDurmont, S. R. Pattyn, E. H. Runyon, H. L. Stanford, I. Tarnok, H. Tasaka, M. Tsukamura, and J. Weiszfeiler. 1977. Cooperative numerical analysis of rapidly growing mycobacteria. The second report. Int. J. Syst. Bacteriol. 27:75-85.

17. Sokal, R. R., and P. H. A. Sneath. 1963. Principles of numerical taxonomy. Freeman and Co., San Francisco.

18. Stanford, H. L. 1973. Immunodiffusion analysis-a rational basis for the taxonomy of mycobacteria. Ann. Soc. Belge Med. Trop. 53:321-330.

19. Szabo, J., and E. Vandra. 1963. Mycobacterium minetti (Penso et al. 1952) bacteriological and epidemiological observation. Acta Microbiol. Acad. Sci. Hung. 10:215223.

20. Tsukamura, M. 1965. Differentiation of mycobacteria by susceptibility to hydroxylamine and 8-azaguanine. J. Bacteriol. 90:556-557.

21. Tsukamura, M. 1965. Salicylate degradation test for differentiation of Mycobacterium fortuitum from other mycobacteria. J. Gen. Microbiol. 41:309-315.

22. Tsukamura, M. 1967. Identification of mycobacteria. Tubercle 48:311-338.

23. Tsukamura, M. 1967. Differentiation of mycobacteria by utilization of nitrogen compounds and carbon sources. Am. Rev. Respir. Dis. 95:307-310.

24. Tsukamura, M., and S. Tsukamura. 1968. Differentiation of mycobacteria by susceptibility to nitrite and propylene glycol. Am. Rev. Respir. Dis. 98:505-506. 